\title{
Survey and Identification of the Level of Readiness of Pandeglang Regency to become a Smart City
}

\author{
Harsiti \\ Information Syst. Dept, Faculty \\ of Information Technology \\ Universitas Serang Raya
}

\author{
Tb. Ai Munandar \\ Informatics Dept, Faculty of \\ Information Technology \\ Universitas Serang Raya
}

\author{
Abdul Malik \\ Communication Scince Dept, \\ Faculty of Social and Political \\ Sciences \\ Univ. Serang Raya
}

\begin{abstract}
Pandeglang Regency is one of the regencies in Banten Province with different regional characteristics and population than other regions. Characteristics of a region that is restricted by mountains and hills and its inhabitants are not too heterogeneous, religious and still maintain their local culture and wisdom. However, this does not prevent the government from realizing Pandeglang Regency as a district that implements the concept of smart city, whose studies have been carried out since 2016 . The study produced three smart city pillars, namely smart monitoring, smart services and smart offices. In its realization, there were still some obstacles caused by several factors, one of which was the availability of human resources in the field of Information Technology. Therefore, it was necessary to do a research to find out the readiness of Pandeglang as a whole in implementing the smart city concept. The results of this study were in the form of a study containing the readiness of Pandeglang in applying the smart city concept based on the fulfillment of the smart city dimension.
\end{abstract}

\section{Keywords}

Characteristics of a region, local culture and wisdom, smart city concept

\section{INTRODUCTION}

The concept of a smart city has been widely applied in various countries, including Indonesia, which has implemented the Smart city concept not only at the provincial and big cities but also at the district level, one of which is Pandeglang Regency. The concept of a smart city is a holistic approach that aims to overcome recent urban challenges and take advantage of the latest opportunities provided by advances in ICT and Urbanization (Mosannenzadeh, Farnaz et al.). The big challenge felt by Pandeglang Regency is the community who stats to become smarter, the development that is always improved, the needs of information that always up-to-date trigger Pandeglang to realize a smart city. The needs of fast service from various parties, both among agencies, communities and business people in Pandeglang cannot be ignored anymore, while the services provided by the government are still considered insufficient.

The development of information and telecommunications technology at this time is expected to be a solution in overcoming urban problems, one of which is by applying the concept of smart city. As an effort to realize the smart city in Pandeglang, studies on 3 pillars have been conducted to support the smart city, namely smart monitoring, smart service and smart office. Another effort is to build a command center called Ruang Pint@r (Pandeglang Informative, Transparent, Accountable and Responsive) inaugurated by the Regent of Pandeglang on August 17, 2017. Ruang Pint@r is managed by the Regional Device Organization (OPD) of the Department of Communication, Informatics, Cypher and
Statistics (DISKOMSANTIK) located in the Regional Secretariat Building which consists of a transit room/guest room, data center/server room, programmer room, meeting room, control room, operator/video wall room and the Regent dashboard room. However, in terms of utilization, it has not maximal yet. Some applications managed by Diskomsantik have been successfully integrated in order to provide information and services to the community, although there are still some obstacles in the implementation, the government of Pandeglang is not tired to develop and improve.

Thus, at a glance, the smart city concept that has been implemented in Pandeglang has been running as it should, however it is necessary to conduct a more detailed study in order to fully realize the smart city concept that meets the 6 pillars of smart city namely smart government, smart environment, smart economy, smart living, smart people and smart mobility. In addition, this effort can also be done to educate the community in order to be able to understand in more detail the concept of smart city for all circles, not only at the government level but also for the wider community and business people in the government of Pandeglang.

\section{LITERATURE REVIEW AND BASIC THEORY}

\subsection{Literature Review}

This research is based on research conducted by previous researchers, such as the research conducted by Kamil Roman in 2018 which discusses the analysis and evaluation of the level of implementation of the concept of smart city in selected cities in Poland. In his research, he successfully surveys 17 selected cities to provide responses regarding the application of the smart city concept. One aspect that is used is the use of information and communication technology to improve the efficiency of the selected regions in functioning cities by observing elements such as the labor market, collaborating with local entrepreneurs, supporting for new businesses (start-ups), collaborating with research and development centers and school or university.

In Indonesia, a survey on the readiness of the implementation of smart city has been carried out in Pakalongan, Central Java, one of the cities in Indonesia that is headed to become a smart city. In Indonesia, a survey on the readiness of the implementation of smart city has been carried out in Pakalongan, Central Java, one of the cities in Indonesia that is headed to become a smart city. The level of readiness is also carried out in Surakarta city by applying the dimension of smart mobility as part of the concept of smart city, where the focus of the research is intelligent mobility, especially public transportation which operates on a certain route.

The big cities in Indonesia that have successfully implemented the smart city concept is the Bandung city with the name of Bandung Smart City 1.0 with four basic 
frameworks in building smart cities that are carried out namely public services, improving apparatus performance, building the interaction of citizens with local government and transparency of data to the public. Whereas, Surabaya implements smart city with the theme of e-government which consists of regional development management and systems for community services (Suhendra, Adi 2017).

\subsection{Basic Theory}

\section{a. Smart city definition}

One of the Smart City's definitions is raised by Supangkat et al., in 2015, that smart city is the development and management of the city by utilizing information and communication technology (ICT) to sense, understand and control various existing resources in the city more effectively and efficiently to maximize service to its citizens and support sustainable development.

The definition of smart city according to A. Caragliu and P. Nijkamp written by Kamil Roman explains that smart city is a place where resources are invested in intellectual capital and innovative infrastructure projects to improve the quality of life and increase satisfaction and prosperity. $\mathrm{K}$ Kourtit and $\mathrm{P}$. Nijkamp believe that Smart City is the result of the increase of knowledge and creativity in making strategic decisions to improve the socio-economic conditions, environment, logistics and competition of the city.

Smart city expert, Boyd Cohen, divides smart city into six main indicators, namely Smart People; Smart Environment, Smart Living, Smart Mobility, Smart Economy and Smart Governance.

\section{b. Readiness level}

The level of readiness is a systematic measurement that supports the assessment of the maturity or readiness of a city. The definition of "readiness" indicates the possibility of a difference between "ready", "not ready yet" and "not ready" of a city. In the Comprehensive Dictionary of Indonesian Language (KBBI), it is stated that readiness comes from the basic word "ready" which means "already available". (Mujiyono et al, 2016)

\section{RESEARCH METHODOLOGY}

\section{The research that was conducted gradually was}

\subsection{Data Collection Phase.}

In the Data Collection Phase, a literature study would be carried out by collecting various references from journals (national/international) and proceedings and conducting agency visits. Furthermore, a Focus Group Discussion (FGD) was held, such as holding meetings and discussions with representatives of relevant agencies and conducting surveys by distributing questionnaires related to the importance of applying the smart city concept and the level of readiness for the application of the smart city concept to government agencies in Pandeglang Regency.

\subsection{Analysis Phase}

At this phase, it was done by using descriptive analysis to draw the results of data collection and processing so that it became a useful information.

\section{RESULTS AND DISCUSSION}

From the research, the thing that has been successfully identified was regarding the availability of indicators used in the survey of the readiness of Pandeglang in applying the smart city concept. This identification was obtained from a literature study by studying several references, reports on the results of studies conducted by the Research Center for Science and Technology, Faculty of Information Technology, University of Indonesia. Focus Group Discussion (FGD) by presenting representatives of agencies in Pandeglang Regency and visiting various agencies. The survey conducted was successfully identifying indicators used to determine the level of readiness of Pandeglang Regency to become a smart city:

a. Identifying the Availability of Village Device Work Units (SKPD) / Regional Device Organizations (OPD)

1) Pandeglang Regency had as many as 33 Regional Device Organizations (OPD) and 70\% (23 OPD) already had a website, but it was not accompanied by a Regent Regulation.

2) There were 35 subdistricts and only $23 \%$ of the subdistricts ( 8 subdistricts) had a website that was currently being evaluated by the Regent. The subdistricts were: Pandeglang Subdistricts, Mandalawangi Subdistricts, Jiput Subdistricts, Keroncong Subdistricts, Sumur Subdistricts and Panimbang Subdistricts.

3) There were 339 villages and only 17 of the villages (5\%) have village portals which were developed but still had problems such as the subdomains used were still different.

b. Identifying the Availability of ICT Services

1) Already had an official website (www.pandeglangkab.go.id)

2) Already had a government data center with the name Ru@ng Pintar (Pandeglang Informative, Transparent, Accountable and Responsive) that was managed by Diskomsantik, but its utilization could not be optimized yet, there were no SOPs related to the operation of the ruang pint@r.

3) Already had a service that was integrated with the Ruang Pintar of the Pandeglang Regency which facilitates the information needs of the community and available work units.

4) Had online services related to public complaints, such as bebeja applications, but its utilization was not optimal yet, complaints from the public have not been responded quickly.

5) Had 17 applications that supported the government services.

6) Had a Youtube Channel as a medium for delivering information directly to the public.

7) Using social media such as Instagram, Twitter, Facebook, WhatsApp as the media for delivering information about government activities to the Public.

8) "Pandeglang Siaga 112" call center service was available during working hours starting from 08.00 to 16.00 Western Indonesian Time.

9) There was no strategic policy in the form of Regent Regulations and Operational Policies in the form of SOPs related to the ICT field.

10) The Hospital Information System was currently being developed which would be integrated with the existing Public Health Center in Pandeglang 
Regency.

11) In the field of education, it has not been identified in detail about the use of applications in each school from kindergarten to senior high school. However, it has implemented the Information System managed by the Central Government in the New Student Admissions Information System.

\section{c. Identifying the Availability of ICT}

Infrastructure

1) Had supporting devices in the form of CCTV cameras installed at 11 spots in all areas of Pandeglang Regency and could be accessed via Mobile for Leaders.

2) CCTV Traffic Control and CCTV Office Monitor have been installed

3) 36 hotspots were installed in 25 subdistricts which were used for the internal government or the public.

\section{d. Identifying Availability of Human Resources}

There was still a lack of human resources in the ICT field.

\section{e. Identifying the Potency for Fulfillment of Smart City Characteristics \\ 1) Smart People}

a. The Subdistrict Internet Service Center Program was available, in collaboration with the Ministry of Communication and Information which has been carried out since 2009 .

b. An internet network has been installed in each subdistrict office that can be accessed by the public.

c. Program of the Global Partnership on Output Based Aid (GPOBA) of the Community Access Point was available in the form of village internet cafe and installation of the village internet cafe equipment.

\section{2) Smart Environment}

a. There was a healthy family pattern program through the Healthy Community Movement (Germas) centered on Panandean, Kupahandap Village, Cimanuk Subdistrict.

b. There was a tourism consciousness program by maintaining the cleanliness and beauty of natural tourism, but this program was still constrained because the community is not fully aware of the importance of a healthy environment, especially in tourism areas. There were still garbages that are dumped on the coast and sea. Overall, Pandeglang Regency had a large area, the details of Pandeglang Regency's total area were $274.689,91$ hectares or 2.747 square kilometers, one third of the urban areas were still lacking of cleaning staff which was only 200 cleaners.

\section{3) Smart Living}

There was a healthy house program aims for a healthy family, but it was not yet fully achieved because of a total of 282,678 households, only $50 \%$ of the households that were recorded by the Health Office paid attention about the health, as many as 141,339 families did not pay attention about the health.

\section{4) Smart Mobility}

The following are transportation potentials that have been owned by Pandeglang Regency including: a. The availability of Rural Transportation. Pandeglang Regency has 4 units of ELP Rural Transportation that were given by the Transportation Agency. This transportation was used as a rural transportation for people in the southern part of Pandeglang, it was free for students/college students.

b. CCTV Traffic Control and CCTV Office Monitor have been installed

c. The existence of the Project application which was an online service application for Pandeglang people with various services including Pro-Pets which provided services to care for pets, bathing, entrusting, buying food or equipment needed for animals. Online shipping and pick-up services include Pro-Food (ordering food and drink), ProRide (shuttle service), Pro-Help (help with all difficulties), and Pro-Shop (shopping and ordering household needs).

d. The existence of Government Development Plan included building the Maja-Rangkasbitung doubletrack railway, reactivating the function of the railway from Rangkasbitung, Lebak to Labuan, in the tourism sector for the Special Economic Zone (KEK) of Tanjung Lesung, the construction of the toll road from Serang to Tanjung Lesung and the establishment of the Airport in Panimbang Subdistrict.

\section{5) Smart Economy}

a. Had a rural area of Mina-Agro Tourism.

b. Had superior products in the form of fruits and local food products.

c. Had areas of agriculture, plantations, fisheries. From the 274.690 hectares of Pandeglang, 239.731 hectares $(87,27$ percent) were used for agricultural businesses such as rice fields, fields, gardens, fishponds, ponds, area for crops, community and state forests. The rest was used for the yards, buildings and courtyards, grasslands, temporarily not cultivated land and so on.

d. Had various tourism areas, there were approximately 30 most-visited tourist attractions(https://wisatalayanan.com/tempatwisata-di-pandeglang/).

e. There was a Pandeglang District Government policy regarding Regional Spatial Plan (RTRW) that was oriented to the development of regional superior potential that has been outlined in the Regional Government Program (PROPEDA) and the Medium-Term Development Plan (RPJM), according to Regional Regulation No. 3 Year 2011.

6) Smart Governance.

a. Pandeglang Regency had as many as 33 Regional Device Organization (OPD) and 70\% (23 OPD) already had a website, but it was not accompanied by a Regent Regulation.

b. There were 35 subdistricts and only $23 \%$ of the subdistricts (8 subdistricts) had a website that was currently being evaluated by the Regent. The subdistricts were: Pandeglang Subdistrict, Mandalawangi Subdistrict, Jiput Subdistrict, 
Keroncong Subdistrict, Sumur Subdistrict and Panimbang Subdistrict.

c. There were 339 villages and only 17 of the villages (5\%) had village portals which were developed but they still had problems including subdomains used that were still different.

d. The construction of a Command Center called Ruang Pint@r (Pandeglang Informative, Transparent, Accountable and Responsive) was inaugurated on August 17, 2017.

e. There were several applications managed by Ruang Pint@r including the guest book of the Ruang Pint@r and applications that were integrated with the existing work units in the government of Pandeglang Regency.

f. Applications that support Smart Services consisted of Online Licensing (SIMPADU), V-Tax, EBPHTB, Bebeja Application, SMS and WA Center (Response and Forward).

g. Applications that supported Smart Monitoring was CCTV Traffic Control, CCTV Office Monitors, Indonesian Disaster Information and Data/DIBI (BPBD), Windy/weather monitor, Bebeja Monitoring Application, Media Analytic/Media Management, applications run by providers to measure the information from printed and electronic media.

h. Application that supported Smart Office which consisted of Regional Financial Management System (SIPKPD), Regional Asset Management System, RKPD Online (Regional Planning System) which has accommodated the results of the Consultation of Development Planning of Village, Subdistrict, Regency and the main of thought of the DPRD members (every member of the DPRD was given an Account to input Programs and Activities), Online E-Absent, E-Hibah Bansos (Replication of mutual cooperation from Bandung), Pro ASN, an application used to manage employee/ASN data, GPS Tracking (Ambulance, Firefighters and Garbage Truck), SIAK (Population Administration Information System) Dashboard, E-mail, ESignature, E-Sakip (managed by the Regional Secretariat organization), Job Position Information System Application, including Job Position Analysis (Anjab) and Workload Analysis (ABK) Documents that could measure employee needs and job position maps and Siskeuda (offline/Village Financial Management Applications)

The Level of Readiness of Pandeglang Regency to Become a Smart City

Based on the survey and the results of the identification of the availability of indicators and characteristics of fulfilling the smart city dimension, it could be concluded that Pandeglang Regency had the potency to implement smart cities that met the four dimensions of smart city, namely smart governance, smart economy, smart mobility and smart people. Its first priority was the smart governance with the reason that its potency had been strengthened by the fields that supported the implementation of a smart city, that was the information and communication technology field.

\section{CONCLUSIONS}

Research that has been carried out was successfully identified some of the potency that has been owned by Pandeglang to become a smart city. The exploration of this potency was carried out based on the results of surveys and agency visits and the Focus Group Discussion which was attended by representatives of agencies in the Subdistrict Environment. The results of the identification of available potential could be concluded that Pandeglang Regency was ready to implement a smart city especially for smart governance, this was because the potential possessed in the government has been supported by some Information and Communication Technology services. The opportunity that Pandeglang had to implement the smart city concept was quite adequate, but it had constraints on the availability of the human resources. Hopefully, this becomes a special concern for the Government of Pandeglang Regency in preparing themselves to become a smart city.

\section{ACKNOWLEDGMENTS}

Acknowledgments are conveyed to the Ministry of Research, Technology and Higher Education which has funded this research with the Higher Education Research Excellence (PTUPT) scheme for the fiscal year of 2018

\section{REFERENCES}

[1] Kamarni, N., 2011, Analisis Pelayanan Publik Terhadap Masyarakat (Kasus Pelayanan Kesehatan Di Kabupaten Agam), Jurnal Manajemen dan Kewirausahaan, Volume 2, Number 3

[2] Wikipedia, 2014, Pelayanan publik, available at https://id.wikipedia.org/wiki/Pelayanan_publik, accessed on March 10, 2016.

[3] F. Mosannenzadeh, D. Vettorato, 2014 - Defining smart city: a conceptual framework based on keyword analysis , TeMA INPUT 2014 Print ISSN 1970-9889, e- ISSN $1970-9870$

[4] Mujiyono, M. Projo Angkasa, Shinta Dewi Rismawati, et al. 2016. Jurnal Litbang Kota Pekalongan VOL. 11

[5] Kourtit, Karima \& Nijkamp, Peter (2012), "Smart Cities in the Innovation Age", The European Journal of Social Science Research, Vol.25, June 2012, 93-95. Routledge

[6] Supangkat, Suhono Harso, el al., (2015), "Pengenalan dan Pengembangan Smart City", LPIK ITB dan SII Smart City Initiatives Forum

[7] Ulya A, Inayatul, Mengukur Kesiapan Kota Dalam Menerapkan Konsep Smart City Inisiatif (Studi Kasus: Kota Banjarmasin), Journal Speed - Sentra Penelitian Engineering dan Edukasi - Volume 9 No 2 - 2017

[8] Christianto, Paminta Agung dkk, Kesiapan Kota Pekalongan menuju Smart City, Jurnal Litbang Kota Pekalongan Volume 11, Year 2016.

[9] Roman, Kamil, Analysis and Evaluation of the Implementation Level of the Smart City Concept in Selected Polish Cities, Broad Research in Artificial Intelligence and Neuroscience, Volume 9, Issue1 (February, 2018), ISSN 2067-8957.

[10] Mosannenzadeh, Farnaz et. al, Defining Smart City. A Conceptual Framework Based on Keyword Analysis, TeMA Journal of Land Use Mobility and Environment INPUT 2014 